\title{
Editorial 2016/XI/1
}

\section{Jana Dlouhá \\ Envigogika 11 (1) - Úvodník/ Editorial}

Published/ Publikováno 16. 9. 2016

DOI: $\underline{10.14712 / 18023061.532}$

Co dělat, a co spíše nedělat, to jsou otázky, které si pravděpodobně klade každý, kdo se snaží pochopit a zároveň vstoupit do současného dění, svou činností je ovlivnit. Jenomže jak? Myriády drobných aktivit se vznáší prostorem, usedají na stránky Facebooku, novinového či jiného zpravodajství a plní rozličné informační kanály. Prostor je jimi přeplněn, připomíná to ale zdokumentovaný, na různých nosičích zachycený růst entropie, což ve svém souhrnu znamená rozklad. Pouze občas se z tohoto všeobecného sestupného pohybu vynořuje osobnost, která jejímu bouřlivému proudění vzdoruje - většinou proto, že uprostřed něho stojí na zemi, víceméně na místě. Nic ( $v$ tomto prostoru viditelného) nekoná. Spíše jen ukazuje, že pasivita není pouhou absencí činnosti, že tomu může být právě naopak: činnost je výsledkem nenaplněné pasivity. Když se člověk zastavuje, rozjímá; rozmýšlí si věci a hledá dưstojnou cestu z momentální situace (chce být nad věcí), svou skutečnost teprve utváŕí. Taková nečinnost je pak stejně důležitá, jako čin, který ji teprve završuje. Vždy, když se zdržujeme komentáře, hlasování, nebo prostě zadržujeme emoce, které nás nutí cosi překotně učinit, ponecháváme prostor pro střetnutí svých přirozených sklonů s rozumem. A právě v tomto střetávání (tedy nikoli pouze v přirozenosti, nebo rozumu samém), je možno hledat základ naší životní moudrosti i všeobecné harmonie člověka a jeho světa.

O pasivitě, její souvislosti s nahodilým, píše ve svém článku Zuzana Svobodová; uvažuje zde o způsobech, jakými jsme vystaveni světu a dějům kolem nás i v nás (uvádíme zde i zajímavé recenzní poznámky k tomuto textu). Autorka vidí, že podstatnou součástí naší každodennosti je nahodilost, kterou nelze plánovat ani jinak manipulovat, a dovozuje, že vědecké poznání je zde k ničemu - orientaci ve světě nahodilého nepomáhá, a nepřispívá ani k rozumnému nakládání s ním. Ono „rozumné" se odkrývá teprve v péči o člověka a jeho domov. Na úvahy filosofického rázu navazuje Lubov Vladyková. Ve svém textu o aplikované ekologické etice dokládá nejen nutnost propojení různých přístupů (vědeckého - filosofického; hledání souladu mezi odlišnými hodnotami); navrhuje též, jaké schopnosti je třeba rozvíjet, aby se člověk dokázal citlivě, a přitom vědomě orientovat ve složitých environmentálních problémech, a při své činnosti být též morální bytostí.

Podobně, jako plodící stromy či vinná réva potřebuji řezem omezovat ve svém růstu, aby vydaly kvalitní plody, tak také člověk musí uznat omezení svých nároků z hlediska sdílené morálky - bude pak snadněji hledat smysl svého života, který by prospíval jemu i dalším lidem. Toho si začínáme být vědomi spíše na mezinárodní úrovni (Františkova encyklika a klimatické dohody z Paříže), zatímco naše domácí praxe zatím příliš změn nepřináší (stále v mnoha ohledech vzhlížíme k minulosti). Úvahy Jiřího Nečase o prosazování klimatické politiky probouzí množství dotěrných otázek - je nám jakýkoli idealismus opravdu vzdálen, překáží naší „svobodě", i kdyby jeoh ideje byly ne-ideální, založené na pragmatickém základě? Bráníme se jim z principu, protože nepatří do našeho přízemně sekulárního světa, nebo již ideologie ne-idealismu tak dobře $v$ našem prostředí zakořenila, že se jí nevzdáme ani z důvodů ryze racionálních? Že zde jde o nový typ racionality založený pohledem do 
budoucnosti, který Ize rozvíjet na logickém základě, dokládá Roman Andres: poskytuje návod, jak se dá adaptace na změnu klimatu (cíl, a tedy úhelný kámen takového uvažování) procvičovat ve školní praxi.

$\mathrm{K}$ tomu, aby politika byla morální, nebo se aspoň k morálce vztahovala jako ke svému referenčnímu rámci, je $v$ našich končinách stále ještě daleko. Rekapitulaci svých zkušeností z vrcholné politiky nabízí Mikuláš Huba, slovenský ochránce př́rody a profesor Geografického ústavu AV SR. Po čtyřech letech strávených ve slovenském parlamentu musí přiznat, že užitečnost se $v$ politickém kalkulu chápe velmi specificky, a politické debaty na tomto utilitárním základě postrádají složku rozumu. Úsilí jednotlivce se této logice postavit je pak vpravdě sysifovské. Tyto morální imperativy (rozum na straně dobra) doplňuje dưrazný požadavek na rozvíjení přirozeného cítění, pohybu, vnímání - orientace v přirozeném světě, kterou člověk (dítě) získává pobytem $v$ nenarušeném přírodním prostředí. Že je čas takto (činorodě, ne však produktivně) strávený základem zdraví a duševní pohody, o tom svědčí zkušenost i četné výzkumy především zahraniční. Nejnovější poznatky přehledně shrnuje Petr Daniš ve své knize Děti venku $v$ prírodě: ohrožený druh? a recenze Envigogiky pouze doplňuje, že je potřeba nejen být ( $v$ přírodě) a vnímat ji (všemi smysly), používat ji jako vitaminu (pro harmonizaci myšlení i fyzických pochodů), ale též chápat prírodu jako svébytnou entitu, $k$ niž se můžeme a máme racionálně přibližovat, aniž bychom ji dokázali plně uchopit (a tedy i podrobit). Dnes je však třeba především hlasitě vyzývat: Jděte (s dětmi) ven!, aby se z přemíry plánovaných („rozumných") dětských aktivit tato nevytratila - to ostatně činí i Petra Hrubošová a Jitka Přerovská z Nadace Proměny Karla Komárka, které představují varovné výsledky výzkumu svědčící o tom, že se tak již děje.

Zdá se, že co je rozumné, a na druhé straně přirozené, se bude vždy znovu (za nových okolností) střetávat - tak jako $v$ tomto čísle Envigogiky. K rozmýšlení a upevnění nového postavení člověka ve světě se možná bude nutné znovu učit rozumět jeho zákonitostem (napríklad je nejprve vnímat v celé přirozené složitosti, popisovat jako "př́padové studie", teprve potom vybírat poznatky, analyzovat je a využívat ku prospěchu člověka - jak uvádí zde představená Metodika prípadových studií), nově definovat cíle vzdělání (jak popisuje recenze publikace dobré praxe ve vysokoškolské výuce Andrey Klimkové), zkoušet se jinak dohodnout na správě svěřeného úseku světa, a to se všemi zúčastněnými (jak je dokáže najít Metodika analýzy aktérů), nebo i vytvářet zcela novou formu poznání (o čemž se diskutovalo na konferenci o nových principech tzv. vědy udržitelnosti, z níz vám přinášíme stručnou zprávu). Př́jemné úvahy nad všemi těmi novotami, jež mají ovšem spíše vyplňovat chybějící prostor pro pasivitu, která je založena $v$ přirozenosti, a kterou právě rozum vhodně doplňuje a překonává, vám opět přeje Envigogika.

...za její redakci

Jana a Jirka Dlouzí 